\title{
HOW DOES CASE-BASED LEARNING STRATEGY INFLUENCE NURSING STUDENTS' CLINICAL DECISION-MAKING ABILITY IN CRITICAL CARE NURSING EDUCATION? AN INTEGRATIVE REVIEW
}

\section{Bahaaeddin M. Hammad (1)}

Inaam A. Khalaf (2)

(1) Lecturer, School of Nursing / The Arab American University, Jenin, Palestine

(2) Professor, Department of Maternal and Child Health Nursing, School of Nursing / The University of Jordan, Amman, Jordan

\section{Corresponding author:}

Bahaaeddin M. Hammad, PhD candidate, MSN, RN.

Lecturer, School of Nursing / The Arab American University, Jenin,

Palestine

Telephone: +970 2418888, +970569344475, Fax: +97042510813.

Email: Bahaa.hammad@aaup.edu

Received: September 2020; Accepted: October 2020; Published: November 1, 2020

Citation: Bahaaeddin M. Hammad, Inaam A. Khalaf. How Does Case-Based Learning Strategy Influence nursing students' clinical decision-making ability in critical care nursing education? An integrative review. Middle East Journal of Nursing 2020; $14(2)$ : 3-8.

DOI: 10.5742/MEJN2020.93791

\section{Abstract \\ Background: Nursing literature consistently indicates that new graduate nurses lack effective clinical decision-making skills when they transition to clinical practice. \\ Method: The integrative review method was used to investigate the published nursing literature regarding the effectiveness of case-based learning strategy on the development of nursing students' clinical decision-making skills in critical care nursing education. Database searches identified 104 studies. Abstracts were screened for relevance, a total of 17 articles were screened for this review. \\ Results: This comprehensive screening process yielded a total of two quantitative, and one qualitative study about the effectiveness of case-based learning strategy on the development of nursing students' clinical decision-making skills. \\ Conclusion: The CBL strategy is considered to be an effective learning strategy that facilitates the development of clinical decision making skills. More rigorous study is warranted to confirm or disprove the findings of this integrative review.}

Key words: clinical decision-making, Nursing education, Case-based learning, student. 


\section{Introduction}

The ultimate goals of nursing education are to produce competent nurses who provide safe, effective and evidence-based nursing care for today's healthcare environments (1). Increasing the complexity and rapid changes in the clinical status of patient population, especially in critical care units, requires nurses who are able to make appropriate and effective clinical decisions (2). Nursing literature consistently indicates however, that new graduate nurses lack effective clinical decisionmaking skills when they transition to clinical practice,(35 ) which may contribute to increased adverse events and errors in the first years of their nursing career $(6,7)$ that negatively impact on patient outcomes $(3,4)$.

Effective clinical decision-making (CDM) has been identified as a cornerstone component of competent nursing practice $(8,9)$. Decision-making is the process of making a choice between a number of alternatives to a course of patient care $(10,11)$. Clinical decisionmaking incorporates a variety of skills including patient data gathering to identify and prioritize patient problems, as well as interpreting and analysing this information to make an appropriate intervention in order to meet all patient needs efficiently and effectively (12). Regardless of the research evidence that CDM skills are one of the essential competencies that should be taking place in nursing education and integrated throughout the nursing curricula, nursing educators are challenged by the diffculty of designing learning environments that facilitate the development of CDM skill sets in nursing students $(13,14)$.

Lectures have historically been the primary teaching strategy adopted in nursing education and remain the main teaching strategy utilized by nursing educators. Nevertheless, the nursing literature reveals that lecturebased learning strategies are an ineffective method used to develop higher order thinking skills such as CDM, as well, lecturing strategies are not welcomed by students, because they do not provide the ground for students' development, motivation and learning (15-18). Lecturebased learning (LBL) strategy does not challenge and encourage nursing students to be involved in the learning process. Also, LBL does not maximize student learning outcomes, which decreases their intention toward learning $(18,19)$. Lecture-based learning is a teacher-centered approach that relies on the passive transfer of knowledge and promotes superficial learning. In lecturing strategy teachers mostly use evaluation methods that reward a learner's ability to reproduce facts without necessarily truly understanding the topic $(20,21)$. Lecturing strategy does not challenge and encourage nursing students to be involved in the learning process. Also, LBL does not maximize student learning outcomes, which can lead to decrease their intention toward learning (19). Active learning strategies such as case-based learning strategy encourages nursing students to be active learners instead of passive learners, and also contribute to building nursing knowledge, promoting high order thinking skills and integrating nursing knowledge to clinical practice $(22,23)$. Case studies are an effective teaching strategy that have been used as a part of traditional classroom, in simulation, and in online courses $(24,25)$.

Case-based learning $(\mathrm{CBL})$ is a teaching strategy within the context of student-centered learning to promote the students' learning and assist them to decide about their prospective field, by the use of case studies $(26,27)$. The instructor in this strategy presents a case scenario that presents a realistic and complex clinical situation and often involves a dilemma, conflict, or problem, which is then followed by various questions related to the case $(26,27)$. Case-based learning has been used in nursing as a teaching strategy, with the aims to develop critical thinking and problem-solving skills $(28,29)$. The cases in CBL contribute to bridging the gap between theory and practice, and between the classroom and the workplace (30).

Utilizing CBL strategy in nursing education has been evident in the nursing literature, and has been explored in a variety of nursing courses and at different level of nursing education(1). But, the majority of these studies were conducted on the effectiveness of this learning strategy regarding critical thinking skills and their impact on integration of nursing theory into clinical practice. While the remaining studies have focused mainly on the students' and faculties' perception and self-reports $(1,15)$. There remains a significant gap in nursing literature as few studies have examined the effectiveness of CBL strategy on the high order thinking skills such as clinical judgment and clinical decision-making skills among undergraduate nursing students $(15,24)$. Therefore, the study was designed to examine the effectiveness of case-based learning strategy on the development of nursing students' clinical decision-making skills in nurse education, specifically in critical care nursing.

\section{Purpose}

The purpose of this integrative review was to examine the effectiveness of case-based learning strategy on the development of nursing students' clinical decisionmaking skills in nurse education, specifically in critical care nursing.

\section{Method}

A comprehensive and systematic search of the Cumulative Index of Nursing and Allied Health Literature (CINAHL), PubMed, Cochrane for systematic review articles, Pro Quest, Scopus, SAGE Journals, Wiley online Library, Google Scholar, Science Direct and EBSCO electronic databases was conducted to obtain relevant studies related to the influence of case-based learning strategy on nursing students' clinical decision making ability in nurse education, specifically in critical care nursing. Key terms used for these searches included: nursing students, casebased learning, case studies, unfolding case studies, and clinical decision making using Boolean operator AND, $\mathrm{OR}$, and NOT to generate the most comprehensive list of available empirical articles. 
Database searches were limited to articles published in English, abstract and peer-reviewed; relevant quantitative, qualitative and mixed methods studies/literature on the area of interest; pertained to nursing education, and nursing student; and CBL used as an education strategy within the field of critical care nursing. No limits were applied for year of publication or methods to ensure that all available manuscripts were retrieved. However, editorial, short communication, letters, non-English and other health professionals or inter-professional studies were excluded. The detailed process of selection is presented in Table 1 (next page).

\section{Results}

\section{The search result}

The initial search in nursing literature failed to identify any study that mainly focused on the effect of CBL strategy on CDM in the field of critical care nursing to date. Therefore, the search was broadened to include all studies that were conducted in a variety of nursing fields. Additionally, searching in electronic databases with a goal of looking for more studies to produce a global picture of the subject with no restriction regarding the publication language was made as long as English abstract was available.

Subsequently, the searching of electronic database yielded a total of 1,036 articles for integrative review. After removing the duplicates 104 studies were assessed for their relevance to the current review purpose. Of these 104 articles, 87 were removed after abstract review. The remaining 17 studies were independently reviewed by the two investigators based on the inclusion criteria previously described. After discussion between the two investigators, unfortunately, 14 studies were excluded. Therefore three studies were included in this integrative review.

Three relevant studies have been reviewed. Each of the studies were extracted into study purpose, design, participant and findings as presented in Table 1. One of these studies was conducted in Japan, 2020(31) and the remaining studies in Korea, 2010, (32) and 2015(33). Video CBL strategy was used as an educational intervention among midwifery and nursing students respectively. One of them used qualitative method approach, an exploratory design (31) while other studies utilized quantitative approach, nonequivalent control group quasi-experimental design $(32,33)$.

Overall, case-based learning strategy was found to be an effective learning strategy to facilitate the development of CDM skills among nursing students in classroom $(31,33)$ and clinical practice environment (32). For example, Nunohara and colleagues (2020) found that case-based leaning strategy contributed to foster the process of clinical decision-making among midwifery students despite CBL approach that has been utilized among midwifery students.

\section{Discussion}

The purpose of this integrative review was to examine the effectiveness of case-based learning strategy on the development of nursing students' clinical decision-making skills in nurse education, specifically in critical care nursing. A comprehensive search of nursing literature for effectiveness of CBL on the development of clinical decision-making skills among nursing students was undertaken, and three studies were found to meet the redefined inclusion criteria. All included studies utilized CBL strategy as an educational intervention. Because of diversity of educational environments, the implementation processes of $\mathrm{CBL}$ strategy as an intervention were different. Also, the outcome measures of CDM skills were not the same.

With only three studies to investigate the effect of CBL strategy on the development of CDM skills in nursing education, this review has indicated that CBL strategy in the field of nursing appears largely unexplored in terms of CDM skills although it has been widely used in nursing to investigate critical thinking skills. All three studies that were included in this review used video case-based approach.

Findings from the reviewed studies provided limited evidence regarding effectiveness of $\mathrm{CBL}$ strategy on the development of CDM skills among nursing students. In two studies(32,33) CDM skills were measured by Jenkins' clinical decision-making in nursing scale, which was developed to describe the perception of the nursing students in clinical decision-making based on their selfexpression(34). Another study used qualitative content analysis method to identify the effectiveness of video case-based approach on CDM processes (31).

Among included studies, video case-based approach was found to be an effective strategy for developing CDM skills among nursing students, (31-33) but this finding cannot be generalized to nursing education, because these studies were limited in terms of small sample size, random allocation to experimental and control groups and implemented one to three case studies in their intervention (31-33). However, lacking robust evidence on this area of interest reflects the gap in nursing literature and the need for further research.

\section{Conclusion}

The CBL strategy is considered to be an effective learning strategy that facilitates the development of clinical decision making skills. This integrative review presents evidence that the use of CBL strategy can promote nursing students' Clinical decision-making skills when compared with lecture based learning. In view of some limitations described earlier, additional robust study with larger samples are warranted in nursing education, critical care nursing in particular, to confirm or disprove the findings of this integrative review. 
Table 1: Literature review matrix

\begin{tabular}{|c|c|c|c|c|c|c|}
\hline$\#$ & $\begin{array}{l}\text { Author(s), date } \\
\text { and title }\end{array}$ & Aim & $\begin{array}{l}\text { Country, } \\
\text { populatio } \\
\text { n, and } \\
\text { sample } \\
\text { size }\end{array}$ & $\begin{array}{l}\text { Article } \\
\text { type, Study } \\
\text { Design }\end{array}$ & $\begin{array}{l}\text { Educational } \\
\text { method }\end{array}$ & $\begin{array}{l}\text { Outcomes and } \\
\text { conclusions }\end{array}$ \\
\hline 1 & $\begin{array}{l}\text { Yoo et al. (2010) } \\
\text { The Effects of } \\
\text { Case-Based } \\
\text { Learning Using } \\
\text { Video on Clinical } \\
\text { Decision Maling } \\
\text { and Learning } \\
\text { Motivation in } \\
\text { Undergraduate } \\
\text { Nursing Students }\end{array}$ & $\begin{array}{l}\text { To examine the } \\
\text { effects of case- } \\
\text { based learning } \\
\text { (CBL) using } \\
\text { video on } \\
\text { clinical } \\
\text { decision- } \\
\text { making and } \\
\text { learning } \\
\text { motivation }\end{array}$ & $\begin{array}{l}\text { Korea } \\
\text { Third } \\
\text { year } \\
\text { nursing } \\
\text { students } \\
(\mathrm{n}=44)\end{array}$ & $\begin{array}{l}\text { Quantitativ } \\
\text { e } \\
\text { Quasi- } \\
\text { experiment } \\
\text { al, non- } \\
\text { equivalent } \\
\text { control } \\
\text { group } \\
\text { design }\end{array}$ & $\begin{array}{l}\text { Intervention } \\
\text { group:video } \\
\text { Case-based } \\
\text { learning. } \\
\text { Control } \\
\text { group: } \\
\text { traditional } \\
\text { classroom } \\
\text { lecture }\end{array}$ & $\begin{array}{l}\text { CBL usingvideo is } \\
\text { effective in } \\
\text { enhandngclinical } \\
\text { decision-maling } \\
\text { and motivating } \\
\text { students to learn } \\
\text { by encouraging } \\
\text { self-directed } \\
\text { learning and } \\
\text { creating more } \\
\text { interest and } \\
\text { curiosity in } \\
\text { learning }\end{array}$ \\
\hline 2 & $\begin{array}{l}\text { Jeong \& Park } \\
(2015) \\
\text { Effects of case- } \\
\text { based learningon } \\
\text { clinical decision } \\
\text { making and } \\
\text { nursing } \\
\text { performancein } \\
\text { undergraduate } \\
\text { nursingstudents }\end{array}$ & $\begin{array}{l}\text { To examine the } \\
\text { effects of case- } \\
\text { basedlearning } \\
\text { (CBL) on } \\
\text { clinical } \\
\text { decision } \\
\text { making and } \\
\text { nursing } \\
\text { performance }\end{array}$ & $\begin{array}{l}\text { Korea } \\
\text { Third } \\
\text { year } \\
\text { nursing } \\
\text { students } \\
(n=55)\end{array}$ & $\begin{array}{l}\text { Quantitativ } \\
\text { e } \\
\text { Quasi- } \\
\text { experiment } \\
\text { al, non- } \\
\text { equivalent } \\
\text { control } \\
\text { group } \\
\text { design }\end{array}$ & $\begin{array}{l}\text { Intervention } \\
\text { group:video } \\
\text { Case-based } \\
\text { learning. } \\
\text { Control } \\
\text { group: } \\
\text { traditional } \\
\text { classroom } \\
\text { lecture }\end{array}$ & $\begin{array}{l}\text { The case based } \\
\text { learning } \\
\text { education } \\
\text { provided to } \\
\text { nursingstudents } \\
\text { during clinical } \\
\text { practice showed a } \\
\text { positive effect of } \\
\text { improvingthe } \\
\text { clinical decision- } \\
\text { making ability and } \\
\text { nursing } \\
\text { performance of } \\
\text { nursingstudents. }\end{array}$ \\
\hline 3 & $\begin{array}{l}\text { Nunohara et al. } \\
(2020) \\
\text { How doesvideo } \\
\text { case-based } \\
\text { learning influence } \\
\text { clinical decision- } \\
\text { making by } \\
\text { midwifery } \\
\text { students? An } \\
\text { exploratory study }\end{array}$ & $\begin{array}{l}\text { To explore the } \\
\text { influence of } \\
\text { video and } \\
\text { paper case } \\
\text { modalities on } \\
\text { the clinical } \\
\text { decision- } \\
\text { making process } \\
\text { of midwifery } \\
\text { students } \\
\text { during CBL }\end{array}$ & $\begin{array}{l}\text { Japan } \\
\text { Midwifer } \\
\text { y nursing } \\
\text { students } \\
(n=45)\end{array}$ & $\begin{array}{l}\text { Qualitative, } \\
\text { Exploratory } \\
\text { design }\end{array}$ & $\begin{array}{l}\text { Intervention } \\
\text { group:video } \\
\text { Case-based } \\
\text { learning. } \\
\text { Control } \\
\text { group:Paper } \\
\text { CBL }\end{array}$ & $\begin{array}{l}\text { This study } \\
\text { clarified the } \\
\text { different } \\
\text { influences of } \\
\text { video andpaper } \\
\text { case modalities } \\
\text { on the clinical } \\
\text { decision-maling } \\
\text { processes of } \\
\text { midwifery } \\
\text { students }\end{array}$ \\
\hline
\end{tabular}




\section{References}

01. Herron, E. K., Powers, K., Mullen, L., \& Burkhart, B. (2019). Effect of case study versus video simulation on nursing students' satisfaction, self-confidence, and knowledge: A quasi-experimental study. Nurse education today, 79, 129-134.

02. Ramazanibadr, F., Nikbakhtenasrabadi, A., Parsayekta, Z. \& Taleghani, F. 2010. Understanding of mental reasoning and clinical decision making criteria of intensive care unit nurses: A qualitative study. J Shahid Beheshti Nurs \& Midwifery, 20, 11-9.

03. Eckerson, C. M. (2018). The impact of nurse residency programs in the United States on improving retention and satisfaction of new nurse hires: an evidence-based literature review. Nurse education today, 71, 84-90.7

04. Goode, C. J., Ponte, P. R., \& Havens, D. S. (2016). Residency for transition into practice: An essential requirement for new graduates from basic $\mathrm{RN}$ programs. JONA: The Journal of Nursing Administration, 46(2), 8286.1

05. Ulrich, B., Krozek, C., Early, S., Ashlock, C. H., Africa, L. M., \& Carman, M. L. (2010). Improving retention, confidence, and competence of new graduate nurses: Results from a 10-year longitudinal database. Nursing economics, 28(6), 363.

06. Brennan, T. A., Leape, L. L., Laird, N. M., Hebert, L., Localio, A. R., Lawthers, A. G., ... \& Hiatt, H. H. (2004). Incidence of adverse events and negligence in hospitalized patients: results of the Harvard Medical Practice Study I. BMJ Quality \& Safety, 13(2), 145-151.

07. Saintsing, D., Gibson, L. M., \& Pennington, A. W. (2011). The novice nurse and clinical decision $\square$ making: how to avoid errors. Journal of Nursing Management, 19(3), 354-359.'

08. Johansen, M. L., \& O’Brien, J. L. (2016, January). Decision making in nursing practice: a concept analysis. In Nursing forum (Vol. 51, No. 1, pp. 40-48).

09. White, K. A. (2013). Development and validation of a tool to measure self-confidence and anxiety in nursing students during clinical decision making. Journal of Nursing Education, 53(1), 14-22.7

10. Thompson, C., \& Dowding, D. (2002). Decision making and judgment in nursing-an introduction. Clinical decision making and judgment in nursing, 1-20.'

11. Thompson, C., \& Stapley, S. (2011). Do educational interventions improve nurses' clinical decision making and judgement? A systematic review. International journal of nursing studies, 48(7), 881-893.

12. Tiffen, J., Corbridge, S. J., \& Slimmer, L. (2014). Enhancing clinical decision making: development of a contiguous definition and conceptual framework. Journal of professional nursing, 30(5), 399-405.]

13. Garrett, B. (2005). Student nurses' perceptions of clinical decision-making in the final year of adult nursing studies. Nurse education in practice, 5(1), 30-39.7
14. Standing, M. (2007). Clinical decision-making skills on the developmental journey from student to Registered Nurse: a longitudinal inquiry. Journal of Advanced Nursing, 60(3), 257-269.

15. Hong, S., \& Yu, P. (2017). Comparison of the effectiveness of two styles of case-based learning implemented in lectures for developing nursing students' critical thinking ability: A randomized controlled trial. International journal of nursing studies, 68, 16-24.

16. Lighthall, G. K., Bahmani, D., \& Gaba, D. (2016). Evaluating the impact of classroom education on the management of septic shock using human patient simulation. Simulation in Healthcare, 11(1), 19-24.7

17. Moonaghi, H. K., Mohammady, A., Moghaddam, A. R. S., Gholami, H., Karshki, H., \& Zamanian, N. (2014). Comparing the Effects of Cooperative Learning to Lecture Trainings on the Motivational Beliefs and Self-Regulating Learning Strategies. Iranian Journal of Medical Education, 14(5).

18. Zhang, J., \& Chen, B. (2020). The effect of cooperative learning on critical thinking of nursing students in clinical practicum: A quasi-experimental study. Journal of Professional Nursing.)

19. Sadeghi, R., Sedaghat, M. M., \& Ahmadi, F. S. (2014). Comparison of the effect of lecture and blended teaching methods on students' learning and satisfaction. Journal of Advances in Medical Education \& Professionalism, 2(4), 146.)

20. Sanaie, N., Vasli, P., Sedighi, L., \& Sadeghi, B. (2019). Comparing the effect of lecture and Jigsaw teaching strategies on the nursing students' self-regulated learning and academic motivation: A quasi-experimental study. Nurse education today, 79, 35-40.'

21. Zhao, B., \& Potter, D. D. (2016). Comparison of lecture-based learning vs discussion-based learning in undergraduate medical students. Journal of surgical education, 73(2), 250-257.

22. Bristol, T., Hagler, D., McMillian-Bohler, J., Wermers, R., Hatch, D., \& Oermann, M. H. (2019). Nurse educators' use of lecture and active learning. Teaching and Learning in Nursing, 14(2), 94-96.

23. Meiers, J., \& Russell, M. J. (2019). An Unfolding Case Study: Supporting Contextual Psychomotor Skill Development in Novice Nursing Students. International journal of nursing education scholarship, 16(1).

24. Carter, J. T., \& Welch, S. (2016). The Effectiveness of unfolding case studies on ADN nursing students' level of knowledge and critical thinking skills. Teaching and Learning in Nursing, 11(4), 143-146.]

25. Dutra, D. K. (2013). Implementation of case studies in undergraduate didactic nursing courses: a qualitative study. BMC nursing, 12(1), 15.

26. McLean, S. F. (2016). Case-based learning and its application in medical and health-care fields: a review of worldwide literature. Journal of Medical Education and Curricular Development, 3, JMECD-S20377.| 
27. Xu, J.-h. (2016). Toolbox of teaching strategies in nurse education. Chinese Nursing Research, 3(2), 54-57.

28. Li, S., Ye, X., \& Chen, W. (2019). Practice and effectiveness of "nursing case-based learning" course on nursing student's critical thinking ability: A comparative study. Nurse education in practice, 36, 91-96'.

29 Yoo, M. S., \& Park, J. H. (2014). Effect of case-based learning on the development of graduate nurses' problemsolving ability. Nurse Education Today, 34(1), 47-51.

30. Barkley, E. F., Cross, K. P., \& Major, C. H. (2014). Collaborative learning techniques: A handbook for college faculty, (2nd ed.). John Wiley \& Sons.]

31. Nunohara, K., Imafuku, R., Saiki, T., Bridges, S. M., Kawakami, C., Tsunekawa, K., ... \& Suzuki, Y. (2020). How does video case-based learning influence clinical decision-making by midwifery students? An exploratory study. BMC medical education, 20(1), 1-10.'

32. Yoo, M. S., Park, J. H., \& Lee, S. R. (2010). The Effects of Case-Based Learning Using Video on Clinical Decision Making and Learning Motivation in Undergraduate Nursing Students. Journal of Korean Academy of Nursing, 40(6).?

33. Jeong, M. E., \& Park, H. S. (2015). Effects of casebased learning on clinical decision making and nursing performance in undergraduate nursing students. Journal of Korean Academy of Fundamentals of Nursing, 22(3), 308-317.

34. Jenkins, H.M. (2001). Cinical decision making in nursing scale. In: Waltz, C.F., Jenkins, L.S. (Eds.), Measurement of Nursing Outcomes volume:1 measuring nursing performance in practice, education and research, Springer Publishing Company, 33-37. 